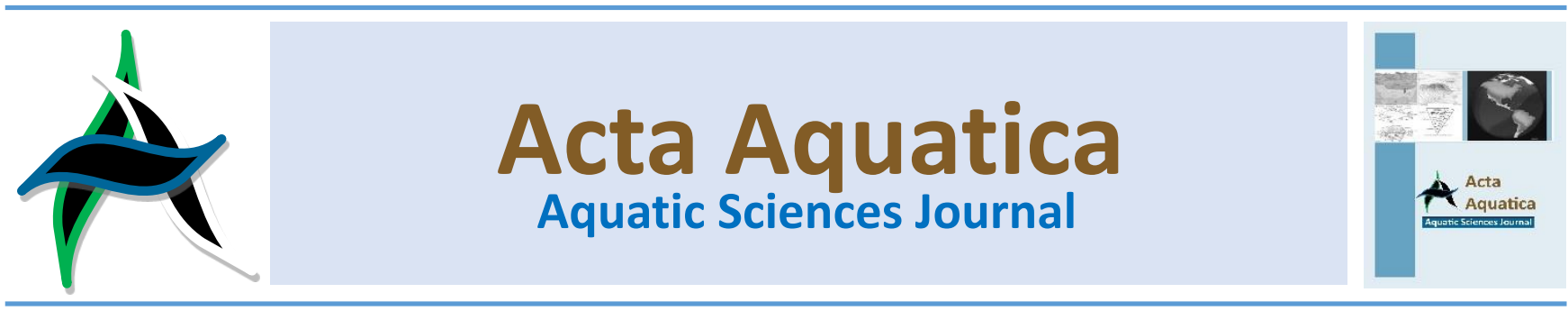

\title{
Aktivitas antibakteri dari ekstrak getah mangrove Excoecaria agallocha pada pelarut kloroform terhadap Escherichia coli dan Staphylococcus aureus
}

\section{Antibacterial activity from the mangrove sap Excoecaria agallocha in chloroform solvent toward Escherichia coli and Staphylococcus aureus}

\author{
Dian Puspitasari ${ }^{\text {* }}$ \\ ${ }^{a}$ Program Studi Budidaya Perairan, Fakultas Pertanian, Universitas Asahan
}

\begin{abstract}
Abstrak
Ekstrak mangrove dari jenis Excoecaria agallocha telah diketahui memiliki berbagai manfaat, seperti yang berasal dari daun, akar, kulit batang dan tidak terkecuali pada getah. Getah ini telah dimanfaatkan untuk meracuni ikan, dan dapat membutakan mata apabila getah masuk kedalam mata walaupun sifatnya sementara. Penelitian ini dilakukan untuk menganalisa adanya aktivitas antibakteri ekstrak getah mangrove E. agallocha menggunakan pelarut kloroform terhadap bakteri Escherichia coli dan Staphylococcus aureus. Tahapan dalam penelitian ini meliputi ekstraksi dan uji aktivitas antibakteri. Penelitian ini menggunakan lima perlakuan meliputi kontrol dan ekstrak kloroform dengan konsentrasi $1 \mu \mathrm{g} /$ disk, $5 \mu \mathrm{g} /$ disk, $10 \mu \mathrm{g} /$ disk dan $50 \mu \mathrm{g} /$ disk. Hasil penelitian menunjukkan bahwa ekstrak getah mangrove $E$. agallocha menggunakan pelarut kloroform dapat menghambat pertumbuhan bakteri $E$. coli dan S. aureus dengan diameter zona hambat yang dihasilkan sebesar $(9,67 \pm 0,32) \mathrm{mm}$ terhadap $E$. coli dan $(11,07 \pm 0,25) \mathrm{mm}$ terhadap S.aureus.
\end{abstract}

Kata kunci: Getah Excoecaria agallocha; Escherichia coli; Staphylococcus aureus

\begin{abstract}
The extract of various plant parts of the mangrove Excoecaria agallocha has been proved as a potential source, for example the extract of leaves, root, bark and also sap. The sap is used for fish poison and temporary blindness if it gets into the eyes. This research for analyse antibacterial activity of extract sap of mangrove $E$. agallocha with kloroform solvent againts Escherichia coli and Staphylococcus aureus. This research include extraction and antibacterial activity test. This experiment use one control and four different concentration of chloroform extract (1 $\mu \mathrm{g} / \mathrm{disc}, 5 \mu \mathrm{g} / \mathrm{disc}, 10 \mu \mathrm{g} / \mathrm{disc}$ dan $50 \mu \mathrm{g} / \mathrm{disc})$. The result showed that the sap extract of mangrove $E$. agallocha with chloroform solvent has antibacterial activity to inhibit $E$. coli dan $S$. aureus growth with minimum inhibitory concentration $(9,67 \pm 0,32) \mathrm{mm}$ to $E$. coli dan $(11,07 \pm 0,25) \mathrm{mm}$ to S.aureus.
\end{abstract}

Keywords: The sap of Excoecaria agallocha; Escherichia coli; Staphylococcus aureus

\footnotetext{
* Korespondensi: Prodi Budidaya Perairan, Fakultas Pertanian, Universitas Asahan. Jalan Jend. Ahmad Yani, Kisaran Naga, Kisaran Tim., Kisaran, Sumatera Utara, Indonesia. 21216

Tel: +62-623-42643, Fax: +62-623-42643.

e-mail:di_dianri@yahoo.com
}

\section{Pendahuluan}

Berbagai penyakit banyak yang muncul, seperti infeks bakteri yang merupakan salah satu masalah dalam bidang kesehatan yang terus berkembang. Obat-obatan yang ada terkadang sudah tidak mampu mengobati karena terjadi resistensi dan harganya yang relatif mahal sehingga perlu dicari alternatif lain, misalnya dengan memanfaatkan bahan alam. Bahan alam sering digunakan sebagai obat tradisional dan pemanfaatannya dilakukan secara turun-temurun serta mudah dalam memperolehnya.

Pencarian bahan antibakteri baru dapat dilakukan dengan pendekatan eksploratif yaitu dengan pengembangan bahan alam. Pemenuhan kebutuhan obat baru yang dilakukan melalui kerja eksploratif ditujukan untuk pencarian variasi struktur senyawa obat yang secara klinis masih digunakan 
dengan memanfaatkan sumber daya alam. Sumber daya alam yang telah dimanfaatkan sebagai sumber bahan obat diantaranya adalah mangrove dari jenis $E$. agallocha.

Pemanfaatan ini meliputi pemanfaatan akarnya yang digunakan sebagai obat sakit gigi, bengkak pada tangan dan kaki, daunnya memiliki potensi sebagai antibakteri maupun antijamur (Agoramoorthy et al., 2007; Dhayanithi et al., 2012), larvasida (Pradeepa et al., 2015), berpotensi sebagai antioksidan dan mempunyai kemampuan sebagai antifilarial (Patra et al., 2009). Batangnya memiliki potensi sebagai anti-HIV (Erickson et al., 1995) dan getah E. agallocha dapat dimanfaatkan sebagai racun ikan (Miles et al., 1999; Rusila et al., 1999), di Malaysia kulit batangnya dapat digunakan sebagai obat pencuci perut (Miles et al., 1999).

Adanya berbagai manfaat tersebut maka tidak menutup kemungkinan bahwa getah E. agallocha memiliki fungsi lain, misalnya sebagai antibakteri. Bakteri yang akan digunakan sebagai bakteri uji adalah Escherichia coli dan Staphylococcus aureus. E.coli adalah bakteri gram negatif. Bakteri E. coli dapat menyebabkan infeksi pada usus yang selanjutnya dapat menyebabkan diare apabila berada dalam kondisi yang tidak normal (Nurwantoro dan Djarijah, 1997). S. aureus adalah bakteri gram positif, bersifat patogen karena dapat menimbulkan penyakit pada manusia, misalnya dapat menyebabkan penyakit infeksi kulit (Volk dan Wheeler, 1973).

Penelitian ini bertujuan untuk menganalisa adanya aktivitas antibakteri ekstrak getah mangrove E.agallocha menggunakan pelarut kloroform terhadap bakteri $E$. coli dan $S$. aureus. Hasil penelitian ini bermanfaat sebagai informasi dibidang farmasi terhadap upaya pencarian bahan antibakteri baru dan dapat digunakan sebagai acuan penelitian lanjutan terkait dengan pengembangan pemanfaatan getah $E$. agallocha sebagai obat antibakteri baru.

\section{Bahan dan metode}

\subsection{Waktu dan tempat}

Sampel getah E. agallocha diambil dari vegetasi mangrove yang berada di pantai Teluk Awur-Jepara.

\subsection{Metode penelitian}

\subsubsection{Ekstraksi sampel}

Ekstraksi dilakukan menggunakan separatory funnel. Sampel dimasukkan ke dalam separatory funnel, kemudian ditambahkan pelarut kloroform. Separatory funnel digojog sampai pelarut bercampur dengan sampel, kemudian didiamkan selama 24 jam. Kedua lapisan dipisahkan dengan cara membuka kran separatory funnel sehingga lapisan bawah mengalir dan ditampung. Ekstraksi diulangi sebanyak 2 kali dengan waktu perendaman 2 jam, sebelum akhirnya dipisahkan. Hasil ekstraksi kemudian dievaporasi dengan rotavapour pada suhu $38^{\circ} \mathrm{C}$. Ekstrak yang diperoleh ditampung dalam vial dan ditimbang.

\subsubsection{Aktivitas uji antibakteri}

Uji aktivitas antibakteri dilakukan dengan metode difusi lempeng agar menurut Kirby-Bauer. Konsentrasi yang digunakan dalam uji antibakteri adalah $1 \mu \mathrm{g} /$ disk, $5 \mu \mathrm{g} /$ disk, $10 \mu \mathrm{g} /$ disk dan $50 \mu \mathrm{g} /$ disk. Media agar (NA) dituang dalam cawan petri steril dan dibiarkan memadat. Inokulum bakteri uji dibuat pada media Nutrien Broth (NB) dengan kepadatan $1 \times 10^{8} \mathrm{CFU} / \mathrm{mL}$, kemudian diinokulasikan keatas media agar yang telah disiapkan dalam cawan petri dan diratakan menggunakan lidi kapas steril. Kertas disk steril diletakkan diatas media yang telah diinokulasikan bakteri uji, peletakan dilakukan secara aseptis menggunakan pinset steril. Kertas disk ditetesi larutan ekstrak yang telah diencerkan menggunakan mikropipet. Konsentrasi ekstrak yang digunakan adalah $1 \mu \mathrm{g} /$ disk, $5 \mu \mathrm{g} /$ disk, $10 \mu \mathrm{g} /$ disk dan $50 \mu \mathrm{g} /$ disk. Selain ekstrak, diujikan juga kontrol (pelarut). Cawan petri diinkubasi pada suhu $37^{\circ} \mathrm{C}$ selama $3 \times 24$ jam. Diameter zona hambat yang terbentuk disekitar kertas cakram diukur menggunakan jangka sorong tiap 24 jam.

\section{Hasil dan pembahasan}

Ekstraksi getah kulit batang E. agallocha dilakukan dengan menggunakan separatory funnel karena sampel berbentuk cair dan dikhawatirkan rusak jika dipanaskan. Ekstraksi cair-cair secara umum digunakan dalam proses separasi atau pemurnian senyawa dari alam maupun senyawa produk dari suatu reaksi kimia (Pavia et al., 1995).

Pengamatan diameter zona hambatan terhadap perbedaan waktu inkubasi (Tabel 1), menunjukkan bahwa diameter zona hambatan yang terbentuk pada waktu inkubasi 24 jam akan mengalami penurunan setelah waktu inkubasi 48 jam dan 72 jam. Penurunan diameter zona hambatan setelah 24 jam, mengindikasikan bahwa senyawa ekstrak bersifat bakteriostatik

Tabel 1

Hasil uji aktivitas antibakteri fraksi dari ekstrak dengan pelarut kloroform.

\begin{tabular}{lccccc}
\hline \multirow{2}{*}{$\begin{array}{c}\text { Bakteri } \\
\text { uji }\end{array}$} & $\begin{array}{c}\text { Konsentrasi } \\
\text { ekstrak }\end{array}$ & \multicolumn{3}{c}{ Diameter zona hambatan $(\mathrm{mm})$} & \multirow{2}{*}{ Ket. } \\
\cline { 3 - 5 } E. coli & $1 \mu \mathrm{\mu g} /$ disk & $10,12 \pm 0,32$ & $9,42 \pm 0,32$ & $9,10 \pm 0,28$ & - \\
& $5 \mu \mathrm{g} /$ disk & $8,65 \pm 0,78$ & $8,05 \pm 0,35$ & $7,70 \pm 0,14$ & - \\
& $10 \mu \mathrm{g} /$ disk & $8,45 \pm 0,49$ & $7,97 \pm 0,46$ & $7,40 \pm 0,78$ & - \\
& $50 \mu \mathrm{g} /$ disk & $8,50 \pm 0,71$ & $8,12 \pm 0,18$ & $7,52 \pm 0,18$ & - \\
\hline S. aureus & $1 \mu \mathrm{g} /$ disk & $10,45 \pm 0,21$ & $9,40 \pm 0,56$ & $9,05 \pm 0,35$ & + \\
& $5 \mu \mathrm{g} /$ disk & $10,17 \pm 0,18$ & $9,30 \pm 0,07$ & $8,75 \pm 0,07$ & - \\
& $10 \mu \mathrm{g} /$ disk & $10,32 \pm 0,25$ & $9,27 \pm 0,04$ & $8,72 \pm 0,32$ & - \\
& $50 \mu \mathrm{g} /$ disk & $9,47 \pm 0,03$ & $8,72 \pm 0,32$ & $8,22 \pm 0,28$ & - \\
\hline
\end{tabular}

Keterangan : ‘+ : ada koloni didalam zona hambat setelah 24 jam : tidak ada koloni didalam zona hambat

Hasil uji aktivitas antibakteri ekstrak dengan pelarut kloroform memiliki spektrum luas, karena mampu menghambat pertumbuhan bakteri $E$. coli dan $S$. aureus pada berbagai konsentrasi. Senyawa antibakteri yang mempunyai daya penghambatan terhadap banyak jenis mikroorganisme baik kokus, basil, maupun spiral disebut senyawa antimikroba yang mempunyai spektrum luas (Dwidjoseputro, 1987).

Menurut Wattimena et al. (1991), bahwa zat antibakteri dikatakan bersifat bakteriostatik bila menunjukkan penyempitan zona hambatan setelah inkubasi 24 jam, sedangkan bakterisidal mampu membentuk zona hambatan yang tetap bening sampai inkubasi 48 jam. Menurut Lay (1994), bahwa lamanya senyawa antimikroba diaplikasikan pada mikroorganisme merupakan salah satu faktor yang mempengaruhi pertumbuhan mikroorganisme dan hal ini juga mengindikasikan bahwa senyawa yang terkandung didalamnya bersifat bakteriostatik. Pertumbuhan bakteri yang terhambat karena zat antibakteri dapat disebabkan oleh (1) penghambatan pada sintesis dinding sel; (2) penghambatan terhadap fungsi membran sel; (3) penghambatan terhadap sintesis protein; dan (4) penghambatan terhadap sintesis asam nukleat (Jawetz et al., 1986).

Ekstrak dengan pelarut kloroform (bersifat semipolar) menunjukkan adanya aktivitas antibakteri terhadap $E$. coli dan $S$. 
aureus. Hal ini diduga karena ekstrak dapat masuk ke tubuh bakteri secara difusi. Dinding sel dan membran sel bakteri mengandung lipid dan ini memudahkan ekstrak yang bersifat non-polar maupun semi polar untuk menembusnya sehingga dapat menggangu pertumbuhannya. Hasil ini sesuai dengan penelitian yang pernah dilakukan, bahwa ekstrak yang bersifat semipolar menunjukkan adanya aktivitas antibakteri. Ekstrak yang bersifat semipolar yang menunjukkan adanya aktivitas antibakteri misalnya pada daun mangrove Cynometra iripa (Choudhury et al., 2005), pada daun mangrove Finlaysonia obovata (Mishra \& Sree, 2007), dan pada daun gambir (Pambayun et al., 2007).

\section{Kesimpulan}

Getah Excoecaria agallocha mempunyai aktivitas antibakteri terhadap Escherichia coli dan Staphylococcus aureus. Perlu dilakukan penelusuran lebih lanjut untuk mendapatkan senyawa aktif murni yang dapat digunakan sebagai bahan antibakteri. Penelitian ini juga perlu dilanjutkan dengan pengujian terhadap mikroorganisme lain (bakteri patogen lain dan jamur) sehingga dapat diketahui lebih luas lagi bioaktivitasnya.

\section{Bibliografi}

Agoramoorthy, G., M. Chandrasekaran, V. Venkatesalu and M.J. Hsu, 2007. Antibacterial and Antifungal Activities of Fatty Acid Methyl Esters of the Blind-your-eye Mangrove from India. Brazillian Journal of Microbiology. 38:739-742.

Choudhury, S., A. Sree, S.C. Mukherjee, P. Pattnaik and M. Bapuji, 2005. In Vitro, Antibacterial Activity of Extracts of Selected Marine Algae and Mangroves against Fish Pathogens. Asian Fisheries Science 18 (2005): 285-294.

Dhayanithi N M, T T A Kumar \& T Balasubramanian, 2012. Effect of Excoecaria agallocha Leaves Againt Aeromonas hydrophila in Marine Ornamental Fish, Amphiprion sebae. Indian J. Mar.Sci. Vol. 41 (1): 76-82.

Dwidjoseputro, D. 1987. Dasar-Dasar Mikrobiologi. Penerbit Djambatan. Jakarta. hlm. 104-144.

Erickson, K.L., J.A. Beutler., J.H. Cardellina., J.B. McMahon., D.J. Newman and M.R. Boyd, 1995. A Novel Phorbol Ester from Excoecaria agallocha. Jounal of Natural Products. 58 (5): 769-772.

Jawetz, E., J.L. Melnick dan E.A. Adelberg, 1986. Mikrobiologi untuk Profesi Kesehatan, Ed. 16. Penerbit Buku kedokteran. Jakarta. hlm. 288-310.

Lay, B.W., 1994. Analisis Mikroba di Laboratorium. PT. Rajagrafindo Persada. Jakarta. $168 \mathrm{hlm}$.

Miles, D.H., U. Kokpol, V. Chittawong, Santi Tip-Pyang, Kwanjai Tunsuwan and Chi Nguyen, 1999. Mangrove Foreststhe Importance of Conservation as a Bioresource for Ecosystem Diversity and Utilization as a Source of Chemical Constituents with Potential Medicinal and Agricultural Value. IUPAC: 1-9.

Mishra, P.M. and A. Sree, 2007. Antibacterial Activity and GCMS Analysis of the Extract of Leaves of Finlaysonia obovata
(A Mangrove Plant). Asian J. Plant Sci., 6(1): 168-172 (2007).

Pambayun, R., M. Gardjito, S. Sudarmadji dan K.R. Kuswanto, 2007. Kandungan Fenol dan Sifat Antibakteri dari Berbagai Jenis Ekstrak Produk Gambir (Uncaria gambir Roxb). Majalah Farmasi Indonesia, 18(3).

Patra, J.K., T. K. Panigrahi, S. K. Rath, N. K. Dhal \& H. Thatoi, 2009. Phytochemical Screening and Antimicrobial Assessment of Leaf Extracts of ExcoecariaAgallocha L.: A Mangal Species of Bhitarkanika, Orissa, India, Adv. in Nat. Appl. Sci., 3(2): 241-246.

Pavia, D.L., Lampman, G.M., Kriz, G.S. and Engel, R.G., 1995. Introductions to Organic Laboratory Techniques: A Contemporary Approach, W.B. Saunders College Publishing. Philadelphia. p 646-662.

Pradeepa, P., K. Subalakshmi., A. Saranya. P. Dinesh., V. A. Raj and T. Ramanathan, 2015. Milky Mangrove Excoecaria agallocha L. Plant as a Source for Potential Mosquito Larvicides. Journal of Applied Pharmaceutical Science. Vol. 5 (03): 102-105.

Radji, M., A. Sumiati dan N. Indani, 2004. Uji Mutagenisitas dan Anti Kanker Ekstrak Aseton dan n-heksana dari Kulit Batang Sesoot (Garcinia picrorrhiza Miq.). Majalah IImu Kefarmasian. 1 (2): $69-78$.

Ren-Bo An, Hyun-Chul Kim, Sung-Hee Lee, Gil-Saeng Jeong, DongHwan Sohn, Hyun Park, Dong-Yeul Kwon, John Hwa Lee and Youn-Chul Kim, 2006. A New Monoterpene Glycoside and Antibacterial Monoterpene Glycosides from Paeonia suffruticosa. Arch Pharm Res. 29 (10): 815-820.

Rusila, N., Y.M. Khazali dan I.N.N. Suryadiputra, 1999. Panduan Pengenalan Mangrove di Indonesia. PKA/WI-IP. Bogor. hlm. 90-98.

Volk, W.A. and M.F. Wheeler, 1993. Mikrobiologi Dasar. Penerbit Erlangga. Jakarta. p 249-260.

Wattimena, J.R., C. Nelly, Sugiarso, M.A. Widianto, E.Y. Sukandar, A.A. Soemardji dan A.R. Setiadi, 1991. Farmakodinamika dan Terapi Antibiotik. Gadjah Mada University Press. Yogyakarta. $168 \mathrm{hlm}$. 